University of Nebraska - Lincoln

DigitalCommons@University of Nebraska - Lincoln

Faculty Papers and Publications in Animal

Science

Animal Science Department

1986

\title{
Effects of Adding Fat to the Sow Lactation Diet on Lactation and Rebreeding Performance
}

G. C. Shurson

Michigan State University

M. G. Hogberg

Michigan State University

N. DeFever

Michigan State University

S. V. Radecki

Michigan State University

E. R. Miller

Michigan State University

See next page for additional authors

Follow this and additional works at: https://digitalcommons.unl.edu/animalscifacpub

Part of the Animal Sciences Commons

Shurson, G. C.; Hogberg, M. G.; DeFever, N.; Radecki, S. V.; Miller, E. R.; and Butler, Win, "Effects of Adding Fat to the Sow Lactation Diet on Lactation and Rebreeding Performance" (1986). Faculty Papers and Publications in Animal Science. 679.

https://digitalcommons.unl.edu/animalscifacpub/679

This Article is brought to you for free and open access by the Animal Science Department at DigitalCommons@University of Nebraska - Lincoln. It has been accepted for inclusion in Faculty Papers and Publications in Animal Science by an authorized administrator of DigitalCommons@University of Nebraska - Lincoln. 


\section{Authors}

G. C. Shurson, M. G. Hogberg, N. DeFever, S. V. Radecki, E. R. Miller, and Win Butler 


\title{
EFFECTS OF ADDING FAT TO THE SOW LACTATION DIET ON LACTATION AND REBREEDING PERFORMANCE ${ }^{1}$
}

\author{
G. C. Shurson, M. G. Hogberg, N. DeFever, \\ S. V. Radecki and E. R. Miller \\ Michigan State University ${ }^{2}$ \\ East Lansing 48824-1225
}

\begin{abstract}
One-hundred-three multiparous sows were randomly assigned to one of two lactation diets containing either no supplemental animal fat (C) or $10 \%$ added fat (F) during two seasons, summer (S) and winter (W), in a $2 \times 2$ factorial arrangement of treatments. Sows were placed on their respective dietary treatments 1 wk prior to farrowing and were fed these diets ad libitum throughout the 28-d lactation period. Weekly feed intake and total feed intake were not affected by diet or season, while weekly metabolizable energy (ME) intake tended to be higher during wk 1 and 3 , and was higher $(\mathrm{P}<.04)$ during wk 2 for sows fed diet $\mathrm{F}$. Sow weight loss from farrowing to $21 \mathrm{~d}$ of lactation and to weaning $(28 \mathrm{~d})$ were unaffected by diet or season. Average pig birth weight was $.15 \mathrm{~kg}$ higher $(\mathrm{P}<.01)$ for pigs born during $S$ compared with those born in $W$. Sows receiving diet $F$ had heavier litters at $21 \mathrm{~d}(\mathrm{P}<.01)$ and heavier average $\mathrm{pig} 21-\mathrm{d}$ weights $(\mathrm{P}<.01)$. This was primarily due to the $13.1 \%$ increase $(P<.04)$ in estimated milk yield and the higher fat concentration $(P<.001)$ of milk consumed by the pigs nursing sows fed diet $F$. Interval between weaning and rebreeding was shortened by $5.9 \mathrm{~d}(\mathrm{P}<.01)$ for sows during $W$ than during $\mathrm{S}$, and tended to be lower for sows fed diet F (7.3 d) compared with that of sows fed diet C $(9.7 \mathrm{~d})$. Farrowing percentage was unaffected by diet but tended to be increased during $W(78.9 \%)$ compared with $S(65.1 \%)$. No differences between season or diet were noted on number of pigs born or number of pigs born alive in the subsequent parity. No diet $X$ season interactions were observed, except for crude protein concentration of sow's milk, which was higher in milk from sows fed diet $C$ during season $W$ $(\mathrm{P}<.04)$.
\end{abstract}

(Key Words: Pigs, Diets, Fat Consumption, Sow Lactation, Reproduction, Return Interval.)

\section{Introduction}

One of the primary factors involved in improving production efficiency in swine operations is to improve sow productivity. This can be accomplished by increasing milk production to produce heavier $21-d$ litter weights and, at the same time, reduce the postweaning rebreeding interval. There is no proven relationship between milk yield during lactation and the length of the postweaning rebreeding interval. Energy status of the lactating sow, season of the year and environmental temperature have all been implicated in observed postweaning anestrus problems (Reese et al.,

\footnotetext{
${ }^{1}$ Journal Article No. 11610 of the Michigan Agr. Exp. Sta.

${ }^{2}$ Anim. Sci. Dept.

Received April 29, 1985.

Accepted October 15, 1985.
}

1982a,b; Cox et al., 1983; Kornegay and Thomas, 1983).

Several researchers have studied the effects of adding fat to the sow's lactation diet on lactation performance as reviewed by Pettigrew (1981). Other researchers have studied the effects of feeding fat to lactating sows on subsequent rebreeding performance (Hughes and Calder, 1979; Reese et al., 1982a,b). Further studies have indicated a reduction in farrowing rate (Hurtgen and Leman, 1980) and a lengthening of the rebreeding interval (Fahmy et al., 1979) during the summer.

Cox et al. (1983) observed a decrease in the weaning-to-estrus interval in sows fed diets containing $10 \%$ added fat during the summer months, while the addition of fat to the sow lactation diet had no effect on the interval from weaning to rebreeding during the winter.

The objective of this study was to evaluate the lactation and rebreeding performance of sows receiving either conventional corn-soybean meal-based diets or diets containing $10 \%$ added fat during the summer and winter seasons. 


\section{Experimental Procedure}

One trial was conducted utilizing a total of 103 multiparous purebred and crossbred sows in a $2 \times 2$ factorial arrangement of treatments. Sows were randomly assigned by parity and breed (Landrace, Yorkshire, Duroc and Landrace $X$ Yorkshire) to one of two experimental diets during one of two seasons. In the first half of the trial, 24 sows were assigned to the control diet (C) and 27 sows were assigned to the diet containing $10 \%$ added fat $(F)$. These 51 sows farrowed during the summer season (S) between July 21 and October 2; litters were weaned at an average of $26.5 \mathrm{~d}$ of age. The second half of the trial utilized a total of 52 sows of which 28 were assigned to diet $C$ and 24 to diet $F$. These sows farrowed during the winter season (W) between December 19 and April 12 and litters were weaned at an average of $26.9 \mathrm{~d}$ of age. Prior to farrowing, gestating sows were housed in individual gestation stalls in a total confinement, mechanically ventilated, gestation facility and were individually fed an average of $2.1 \mathrm{~kg} \cdot$ head $^{-1} \cdot \mathrm{d}^{-1}$ of a cornsoybean meal-gestation diet that met or exceeded all NRC requirements for nutrients (NRC, 1979). Gestation diet composition and calculated analyses are shown in table 1 . On approximately d 107 of gestation, sows were moved to the farrowing facility and fed their assigned experimental diets ad libitum. Lactation diet composition and analyses ${ }^{3}$ are shown in table 1. Lactating sows remained on their respective lactation diets until the litters were weaned.

Daily high and low temperatures were recorded using high-low thermometers located in each farrowing room. Individual sow weights were recorded at $1 \mathrm{~d}$ post-farrowing, $21 \mathrm{~d}$ of lactation and at weaning. Weekly feed intakes for wk 1, 2 and 3 of lactation were recorded for 39 sows, fed ad libitum ( 16 sows fed diet $C$ and 23 sows fed diet F) during the summer months of the trial, while feed intakes from 31 sows, fed ad libitum ( 18 sows fed diet $\mathrm{C}$ and 13 sows fed diet F) were recorded during the winter months. The number of pigs born, born alive

\footnotetext{
${ }^{3}$ A commercial dried fat (Merrick 4-80), containing ether extract and $4 \%$ crude protein, provided $10 \%$ supplemental animal fat when added at $12.5 \%$ of the lactation diet; supplied by Merrick Foods, Inc., Union Center WI.
}

and weaned per litter were recorded. Pigs were transferred between litters within dietary treatment before $3 \mathrm{~d}$ of age in an attempt to standardize litter size to 10 pigs/litter; the number of pigs per litter after transfer was recorded. Litter weights were recorded at birth and $21 \mathrm{~d}$ of age. A $30-\mathrm{ml}$ milk sample was collected from each sow at $21 \mathrm{~d}$ of lactation after administering 60 USP units of oxytocin im, washing the udder with warm water and then drying with paper towels. Uniform amounts of milk were extracted from all functional teats on one side of the sow's udder. Milk samples were stored in plastic jars and frozen at $-20 \mathrm{C}$ until analyzed for milk fat and nitrogen. Nitrogen content of milk samples was determined in duplicate by using a semi-micro Kjeldahl method (AOAC, 1984; crude protein = $6.25 \times \mathrm{N}$ ); total fat content was determined by the Roese-Gottlieb method (AOAC, 1984). Estimated milk yield for each sow was determined using a regression equation relating pig weight gain to milk yield (Lewis et al., 1978). Pigs were not given creep feed but did have access to sow's feed.

At weaning, the date and sow weights were recorded as the sows were moved to individual gestation stalls in the breeding facility and checked daily for estrus. Each boar pen was located adjacent to each group of six gestation stalls; sows were hand-mated twice while they were in estrus. Breeding dates were recorded and were used to determine the number of days between weaning and rebreeding. If sows did not display estrus within 2 wk after weaning, subsequent rebreeding dates were recorded and used to calculate the days from weaning to rebreeding interval. Subsequent litter size, which included the number of pigs born and born alive, was recorded for all sows based upon their previous lactation diet treatment. Data were statistically analyzed by method of least-squares for the main effects of diet and season, along with the diet $X$ season interaction (Gill, 1978); simple correlations between all pairs of measured variables were calculated.

\section{Results and Discussion}

Weekly feed intake and total feed intake for (34 of the 52) sows fed lactation diet $F$ were not different than for ( 36 of the 51 ) sows receiving lactation diet $\mathrm{C}$ (table 2 ). Weekly metabolizable energy (ME) intake tended to be higher during wk 1 and 3 , and was higher $(\mathrm{P}<.04)$ during wk 2 for sows fed diet $\mathrm{F}$. No 


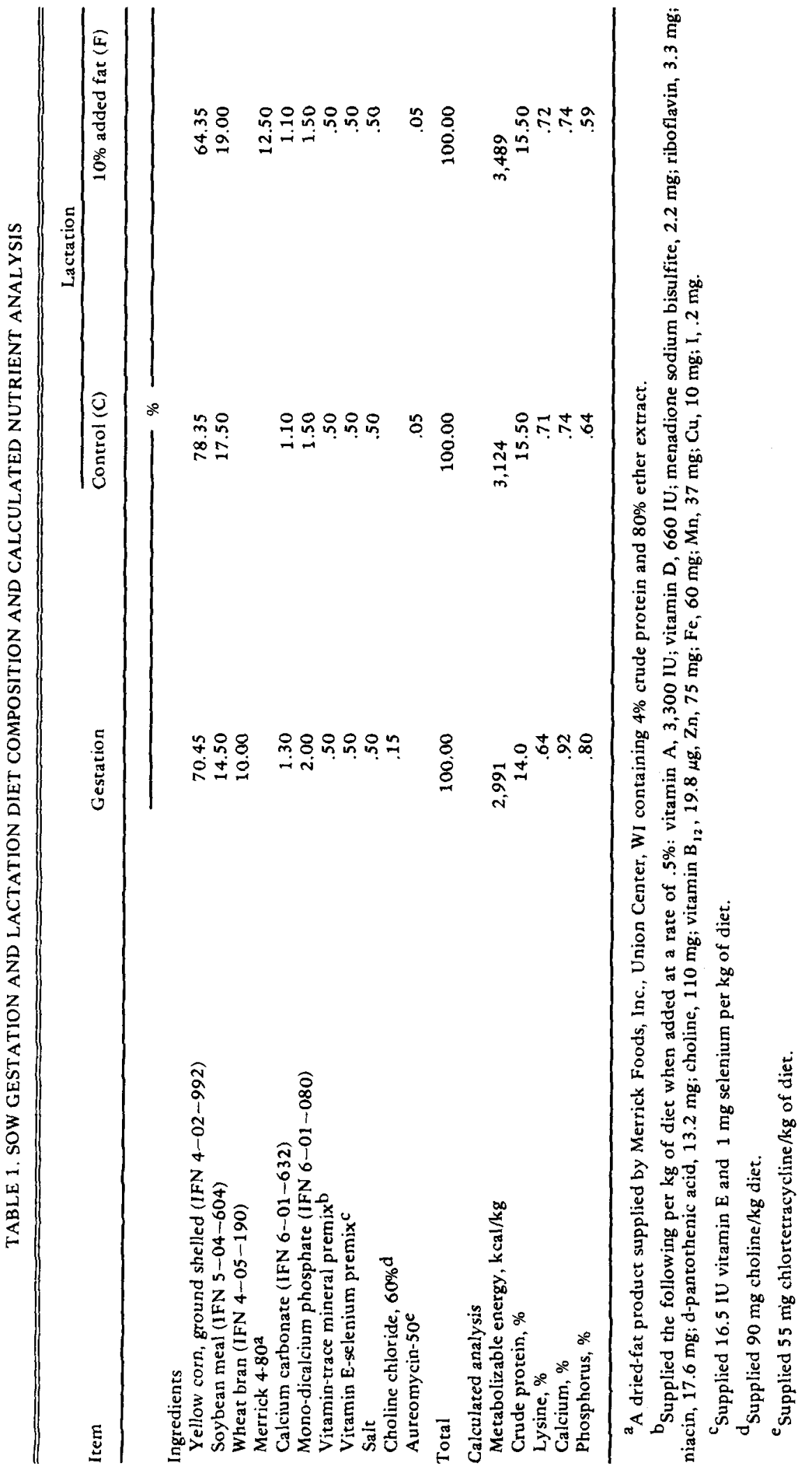


seasonal differences were noted for weekly feed intake, total feed intake or weekly ME intake. These results are consistent with work reported by Seerley et al. (1981) in which no differences were noted in feed intake between sows fed control, $10 \%$ supplemental corn oil or $10 \%$ supplemental animal fat diets, and with work reported by Cox et al., (1983) where $10 \%$ dietary fat supplementation and season had no effect on daily feed intake. Added fat in the lactation diet increased daily $M E$ intake in sows (Stahly et al., 1980). However, several researchers have reported that daily feed intake was lower when lactating sows were fed diets containing supplemental fat due to the increased caloric density of the diet (Boyd et al., 1978, 1982; Pollman et al., 1980).

Average weekly high temperature in the farrowing facility was approximately $3.0 \mathrm{C}$ higher $(\mathrm{P}<.001)$ during the summer season $(\mathrm{X}=26.9 \mathrm{C})$ than during the winter season $(\bar{X}=23.8 \mathrm{C})$, which is slightly higher $(2.3 \mathrm{C})$ than the average daily high temperature in farrowing rooms between seasons reported by Cox et al. (1983). Furthermore, average weekly temperature was an average of $1.8 \mathrm{C}$ higher $(\mathrm{P}<.001) \quad(\overline{\mathrm{X}}=24.2$ vs $22.4 \mathrm{C})$ and average weekly temperature range was $2.7 \mathrm{C}$ greater $(\mathrm{P}<.001 ; \mathrm{X}=5.5$ vs $2.8 \mathrm{C})$ during $\mathrm{S}$ than in $\mathrm{W}$. The higher average weekly temperature range is probably not of the magnitude necessary to affect feed intake, but may have affected lactation and rebreeding performance of sows due to a higher level of stress produced from higher environmental temperatures or wider temperature fluctuations in the farrowing facility. Average low temperature was not different for $\mathrm{S}$ and $\mathrm{W}$ seasons except during the third week of lactation when it was $1.4 \mathrm{C}$ higher $(\mathrm{P}<.02)$ during $\mathrm{S}(21.9 \mathrm{C})$ than during $\mathrm{W}$ $(20.5 \mathrm{C})$. This difference might be explained by the lack of temperature control imposed by the summer climate as compared with that during the winter in a total confinement, environmentally controlled farrowing facility.

Sow weight loss from farrowing to $21 \mathrm{~d}$ of lactation, and to weaning, were unaffected by diet or season (table 3). Sows fed diet C lost $10.8 \mathrm{~kg}$; sows fed diet $F$ lost $11.2 \mathrm{~kg}$ from farrowing to weaning but sows tended to lose more weight during the lactation period in $\mathrm{S}$ $(13.7 \mathrm{~kg})$ than $\mathrm{W}(8.2 \mathrm{~kg})$. Cox et al. (1983) indicated that fat supplementation in the sow lactation diet had no effect on reducing weight loss during the summer, but during the winter,

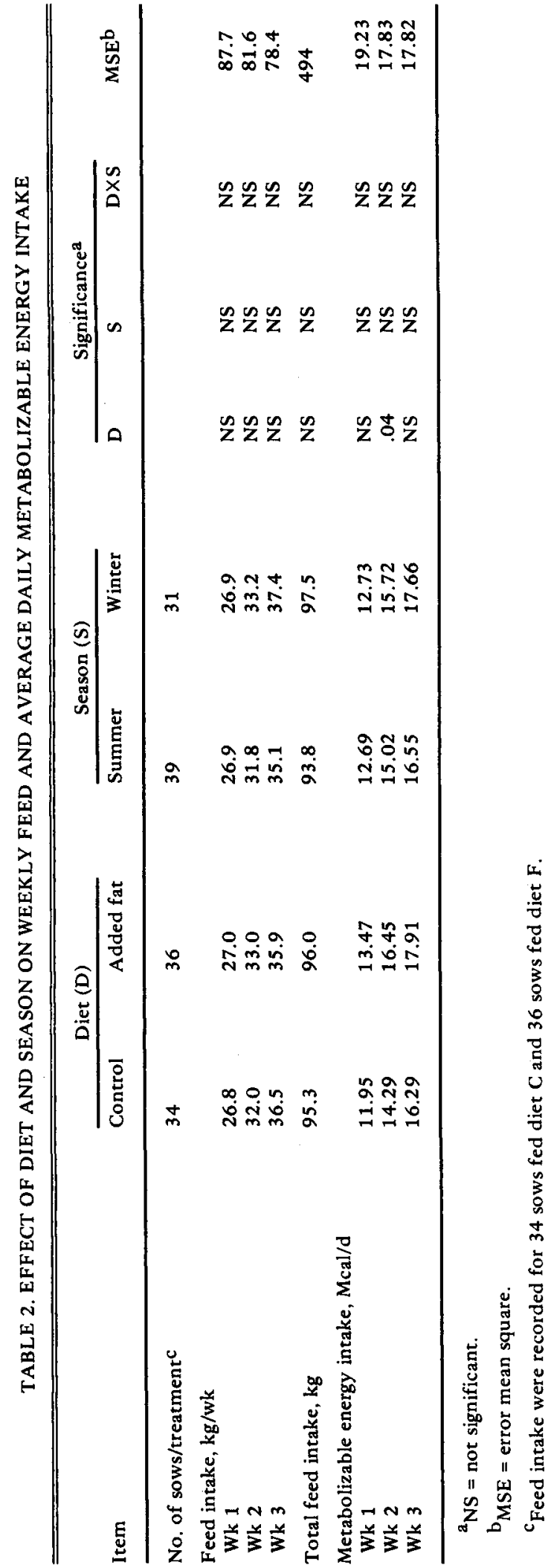




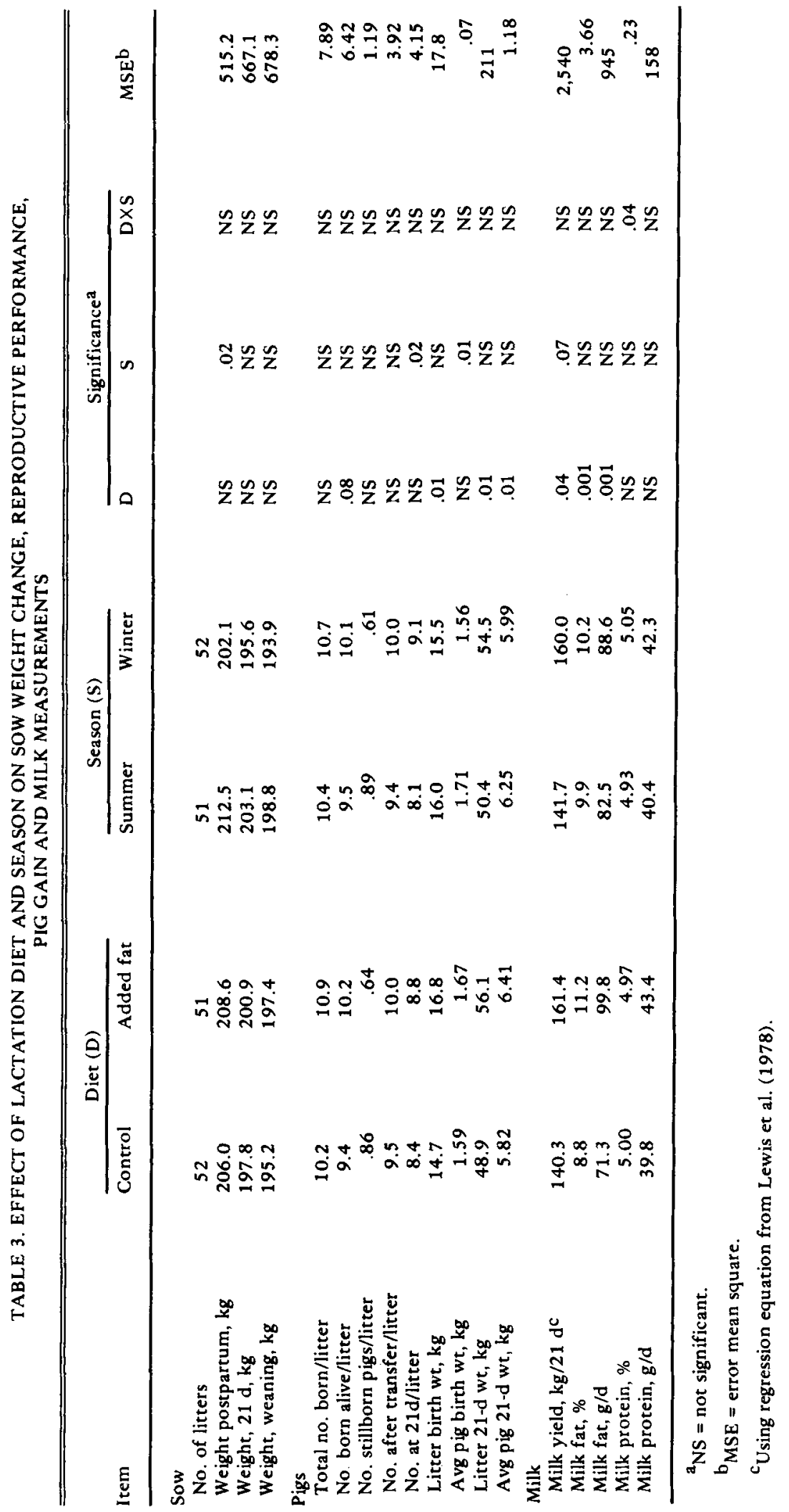


sows fed the $10 \%$ fat-supplemented diet lost more weight than sows fed the control diet. However, Cox et al. (1983) indicated that supplementing the diet with fat reduced the number of days to estrus following weaning in summer, but did not affect this interval in winter. Our results are consistent with work by Seerley et al. (1981) in which there were no differences in weight loss between sows fed control, $10 \%$ corn oil or $10 \%$ animal fatsupplemented lactation diets. Reese et al. (1984) observed that sows receiving $8 \mathrm{Mcal}$ of $\mathrm{ME} / \mathrm{d}$ lost more weight during lactation than sows receiving $16 \mathrm{Mcal}$ of $\mathrm{ME} / \mathrm{d}$. Differences in sow weights post-farrowing between seasons $(\mathrm{P}<.02)$ may have resulted from differences in weights of sows when allotted to dietary treatments prior to farrowing.

Total number of pigs born/litter was not different between dietary treatments or seasons (table 3). Because dietary treatments were not imposed until d 107 of lactation, no effect due to diet would be expected. Number of piglets born alive/litter was higher $(\mathrm{P}<.08)$ from sows fed diet F (10.2) compared with sows fed diet C (9.4). Number of stillborn pigs was not different between diets or seasons, which is consistent with work reported by Cieslak et al. (1983) where neither the number of live births/litter nor the number of stillbirths/litter was affected by increasing the fat content of the diet. Litter birth weights were greater $(\mathrm{P}<.01)$ for sows fed diet $\mathrm{F}(16.8 \mathrm{~kg})$ compared with sows fed diet $C(14.7 \mathrm{~kg})$, which is a direct result of the higher number of pigs born alive because there were no diet differences in average pig birth weight. These results are consistent with previous studies where average birth weights of live pigs were unaffected by fat supplementation in the sow diet (Seerley et al., 1974; Okai et al., 1977; Boyd et al., 1978; Seerley et al., 1978; 1981). Average pig birth weight was higher $(\mathrm{P}<.01)$ during $\mathrm{S}(1.71$ $\mathrm{kg}$ ) than during $\mathrm{W}(1.56 \mathrm{~kg})$. The increased number of pigs weaned/litter during $\mathrm{W}(\mathrm{P}<.02)$ may be due to the greater milk yield $(P<.06)$ of sows during $\mathrm{W}$, even though the average birth weight was less $(\mathrm{P}<.01)$ during the winter than the summer. It is well documented that heavier birth weights increase pig survival. Fahmy and Bernard (1971) reported $2.9 \%$ mortality among pigs weighing $1.6 \mathrm{~kg}$ or more at birth, with a gradual increase in death rate with decreasing birth weight up to $81.7 \%$ mortality among pigs weighing less than $.45 \mathrm{~kg}$ at birth.
Thus, because of the high average birth weight of pigs from litters during both summer and winter seasons, 1.71 and $1.56 \mathrm{~kg}$, respectively, the difference in birth weights may not have been of major consequence on the survival of pigs to $21 \mathrm{~d}$, and probably milk yield was a more important factor contributing to improved survival of pigs during the $W$.

Sows receiving diet $F$ had heavier litter weights at $21 \mathrm{~d}(\mathrm{P}<.01)$ and heavier average piglet 21-d weights $(P<.01)$ than litters from sows receiving diet $C$, but there were no seasonal differences. Pigs nursing sows fed diet $F$ tended $(\mathrm{P}<.09)$ to gain more weight from birth to $21 \mathrm{~d}$ of age $(4.41 \mathrm{~kg})$ than pigs nursing sows fed diet $C(4.04 \mathrm{~kg})$, while no seasonal differences were observed. Similarly, litter weight gain from birth to $21 \mathrm{~d}$ of age was greater for pigs nursing sows receiving diet $F$ compared with pigs nursing sows receiving diet $\mathrm{C}, 39.3 \mathrm{~kg}$ and $34.1 \mathrm{~kg}$, respectively $(\mathrm{P}<.04)$. Furthermore, litters from sows farrowing during $\mathrm{W}$ tended to gain more weight from birth to $21 \mathrm{~d}$ of age than litters from sows farrowing during $S, 38.9 \mathrm{~kg}$ and $34.5 \mathrm{~kg}$, respectively $(\mathrm{P}<.07)$. Boyd et al. (1982) observed heavier weaning weights of pigs from sows receiving fat-supplemented diets. O'Grady et al. (1973) found a positive correlation between sow energy intake and 21-d pig weights. The combination of number weaned and weight at weaning improved total litter weaning weight by $5.1 \mathrm{~kg}$ when sows were fed fat-supplemented diets (Cieslak et al., 1983). Other researcers have found no differences in average 21-d litter weight (Seerley et al., 1981) or litter weaning weights (Cox et al., 1983) of pigs from sows receiving diets containing supplemental fat. Cox et al. (1983) found no difference in weaning weights between seasons.

Estimated milk yield was increased $13.1 \%$ by feeding diet $F$ to sows $(P<.04)$ and was also $11.4 \%$ greater $(P<.07)$ during $W$ compared with $S$ (table 3 ). Other workers have suggested that milk yield was improved by 10 to $17 \%$ by feeding fat to sows (Kruse et al., 1977; Pettigrew, 1978). Milk yield and milk composition are associated with the rate of growth and development of the young pig (Fahmy, 1972; Lewis et al., 1978). Thus, the greater number of pigs at $21 \mathrm{~d}$ during the winter season and the heavier 21-d litter weights from sows receiving the $10 \%$ supplemental fat diet were probably due to the increased milk yield as well as to the increase in milk fat $(\mathrm{P}<.001)$ con- 
sumed by the pigs, which provided more energy for growth. Fat concentration (11.2\%) of milk from sows fed diet $F$ was greater $(P<.001)$ than that $(8.8 \%)$ of milk from sows fed diet $C$. These concentrations are consistent with several reports (Boyd et al., 1978; Stahly et al., 1980; Pettigrew, 1981; Boyd et al., 1982; Lellis and Speer, 1983). Fat concentration of sow's milk has been reported to range from 3.0 to $21.1 \%$ (Neuhaus, 1961) and from 3.5 to $10.5 \%$ (Pond and Houpt, 1978). These large variations in milk fat content probably reflect differences in sampling techniques and analytical procedures employed in the various studies. Grams of milk fat consumed $\cdot \mathrm{pig}^{-1} \cdot \mathrm{d}^{-1}$ was calculated to be $71.3 \mathrm{~g}$ for pigs nursing sows fed diet $\mathrm{C}$, while pigs consumed more fat $(99.8 \mathrm{~g}) \quad(\mathrm{P}<.001)$ when nursing sows that were fed diet F. Grams of milk fat consumed $\cdot \mathrm{pig}^{-1} \cdot \mathrm{d}^{-1}$ was not affected by season. No differences between diet or season were observed for crude protein content of milk or $\mathrm{g}$ crude protein consumed $\cdot$ pig $^{-1} \cdot \mathrm{d}^{-1}$.

The interval between weaning and rebreeding was $5.9 \mathrm{~d}$ shorter during season $\mathrm{W}$ than during season $S$ (table $4 ; \mathrm{P}<.01$ ), and tended to be lower for sows fed diet $F(7.25 \mathrm{~d})$ than for sows receiving diet $C(9.69 \mathrm{~d})$. Farrowing percentage was unaffected by diet, but tended to increase during W (78.9\%) compared with $S$ $(65.1 \%)$. Researchers have reported a decline in farrowing rate (Hurtgen and Leman, 1980) and a lengthening of the rebreeding interval (Fahmy et al., 1979; Cox et al., 1983) during the summer season. Body weight loss by the sow during lactation has been shown to have a direct effect on rebreeding performance (Reese et al., 1982a). Hughes and Calder (1979) and Reese et al. (1982a,b) demonstrated that increasing energy intake during lactation can reduce the number of days to rebreeding. However, Varley and Cole (1976) reported no effect of feeding level during lactation on the number of days to return to estrus following weaning, even though sow weight loss was affected by feeding level during lactation. Since no differences were observed in sow weight loss in this study, other factors must account for the difference in rebreeding interval.

Average weekly high temperature and average weekly temperature range had the highest correlation with the number of days to rebreeding during wk 3 of lactation ( $r=.50$ and $r=.48$, respectively), while average daily temperature had a correlation of $r=.33$ with days to

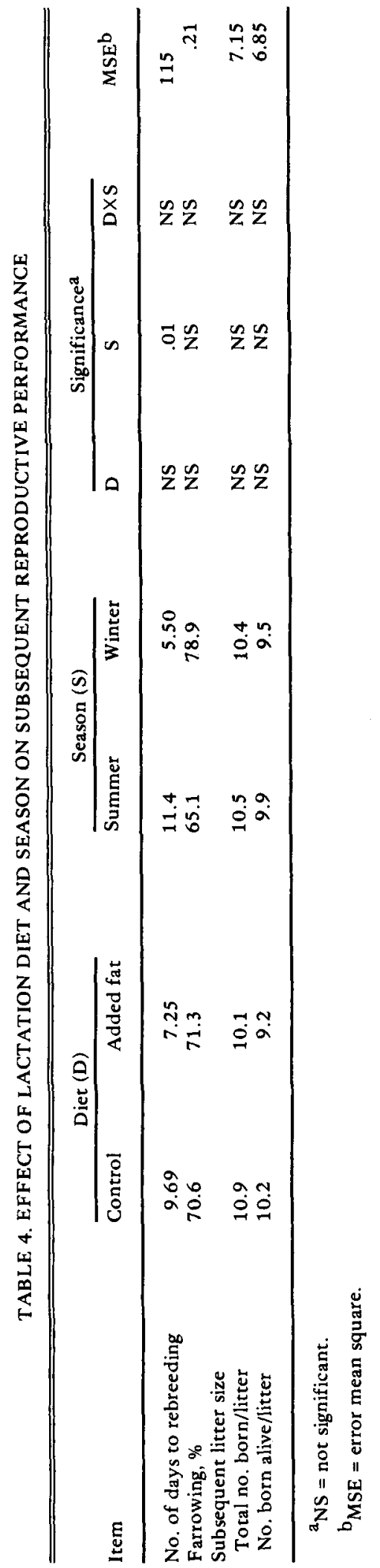


TABLE 5. CORRELATIONS BETWEEN FARROWING HOUSE TEMPERATURES OR DAILY ENERGY INTAKE (TRAIT 1) WITH THE NUMBER OF DAYS FROM WEANING TO REBREEDING (TRAIT 2)

\begin{tabular}{|c|c|c|}
\hline Trait 1 & $\mathbf{r}^{\mathbf{a}}$ & Significance $b$ \\
\hline \multicolumn{3}{|c|}{ Avg weekly high temperature } \\
\hline Wk 1 & .37 & .01 \\
\hline Wk 2 & .45 & .01 \\
\hline Wk 3 & .50 & .01 \\
\hline \multicolumn{3}{|c|}{ Avg wèekly temperature } \\
\hline Wk 1 & .26 & .05 \\
\hline Wk 2 & .34 & .01 \\
\hline Wk 3 & .33 & .01 \\
\hline \multicolumn{3}{|c|}{ Avg weekly temperature range } \\
\hline Wk 1 & .36 & .01 \\
\hline Wk 2 & .38 & .01 \\
\hline Wk 3 & .48 & .01 \\
\hline \multicolumn{3}{|c|}{ Avg daily energy intake, kcal MEC } \\
\hline Wk 1 & -.14 & NS \\
\hline Wk 2 & -.06 & NS \\
\hline Wk 3 & -.16 & NS \\
\hline
\end{tabular}

${ }^{a}$ Correlation coefficient between trait 1 and trait 2.

${ }^{b} \mathrm{NS}=$ not significant.

$c_{M E}=$ metabolizable energy.

rebreeding at wk 3 of lactation (table 5). Inconclusive results regarding the influence of temperature on rebreeding interval have been reported (Hurtgen and Leman, 1980; Hurtgen et al., 1980; Cox et al., 1983; Kornegay and Thomas, 1983). Correlations berween temperature and the number of days to rebreeding observed in this study tend to suggest that high temperatures or increased temperature range may have some detrimental effect on rebreeding performance. Daily energy intake and season apparently have no effect on rebreeding performance, as exemplified by the low correlations observed in this study (table 5 ). This is consistent with research by Cox et al. (1983) in which there was no effect of feed intake within or between seasons on the weaning-to-estrus interval. Perhaps photoperiod or a combination of contributions from several factors affect rebreeding performance. Subsequent litter size of sows in relation to the total number of piglets born or born alive was not affected by dietary treatment or season.

\section{Literature Cited}

AOAC. 1984. Official Methods of Analysis (14th Ed.). Association of Official Analytical Chemists, Washington, DC.

Boyd, R. D., B. D. Moser, E. R. Peo, Jr. and P. J. Cunningham. 1978. Effect of energy source prior to parturition and during lactation on piglet survival and growth and on milk lipids. J. Anim.
Sci. 47:883.

Boyd, R. D., B. D. Moser, E. R. Peo, Jr., A. J. Lewis and $R$. K. Johnson. 1982. Effect of tallow and choline chloride addition to the diet of sows on milk composition, milk yield and preweaning pig performance. J. Anim. Sci. 54:1.

Cieslak, D. G., V. D. Leibbrandt and N. J. Benevenga. 1983. Effect of a high fat supplement in late gestation and lactation on piglet survival and performance. J. Anim. Sci. 57:954.

Cox, N. M., J. H. Britt, W. D. Armstrong and H. D. Alhusen. 1983. Effects of feeding fat and altering weaning schedule on rebreeding in primiparous sows. J. Anim. Sci. 56:21.

Fahmy, M. H. 1972. Comparative study of colostrum and milk composition of seven breeds of swine. Can. J. Anim. Sci. 52:621.

Fahmy, M. H. and C. Bernard. 1971. Causes of mortality in Yorkshire pigs from birth to 20 weeks of age. Can. J. Anim. Sci. 51:351.

Fahmy, M. H., W. B. Holtmann and R. D. Baker. 1979. Failure to recycle after weaning and weaning to oestrus interval in crossbred sows. Anim. Prod. 29:193.

Gill. J. L. 1978. Design and Analysis of Experiments, Vol. 1 and 3. The Jowa State Univ. Press, Ames.

Hughes, P. E. and A. F. Calder. 1979. The effect of lactation feed level on weight change and reproductive performance in the sow. Anim. Prod. 28: 444(Abstr.).

Hurtgen, J. P. and A. D. Leman. 1980. Seasonal influence on the fertility of sows and gilts. J. Amer. Vet. Med. Assoc. 177:631.

Hurtgen, J. P., A. D. Leman and B. Crabo. 1980. Seasonal influence on estrous activity in sows and gilts. J. Amer. Vet. Med. Assoc. 176:119.

Kornegay, E. T. and H. R. Thomas. 1983. Effect of 
air-conditioned versus naturally ventilated housing during hot weather on the reproductive efficiency of gilts or sows. Livestock Prod. Sci. 10: 387.

Kruse, P. E., V. Danielsen, H. E. Nielsen and K. Christensen. 1977. The influence of different dietary levels of linoleic acid on reproductive performance and fatty acid composition of milk fat and plasma lipids in pigs. Acta Agr. Scand. 27:289.

Lellis, W. A. and V. C. Speer. 1983. Nutrient balance of lactating sows fed supplemental tallow. J. Anim. Sci. 56: 1334.

Lewis, A. J., V. C. Speer and D. C. Haught. 1978. Relationship between yield and composition of sow's milk and weight gain of nursing pigs. J. Anim. Sci. 47:634.

Neuhaus, V. U. 1961. Die milchleistung der sau und die zusammensetzung und eigenschaften der sauenmilch. Z. Tierz. Zuchtungsbiol. 75:160.

NRC. 1979. Nutrient Requirements of Domestic Animals, No. 2. Nutrient Requirements of Swine. Eighth Revised Ed. National Academy of Sciences - National Research Council, Washington, DC.

O'Grady, J. F., F.W.H. Elsley, R. M. MacPherson and I. McDonald. 1973. The response of lactating sows and their litters to different dietary energy allowances. 1. Milk yield and composition, reproductive performance of sows and growth rate of litters. Anim. Prod. 17:65.

Okai, D. B., F. X. Aherne and R. T. Hardin. 1977. Effect of sow nutrition in late gestation on the body composition and survival of the neonatal pig. Can. J. Anim. Sci. 57:439.

Petrigrew, J. E. 1978. Supplemental fat in sow diets. Proc. Pacific NW Pork Exposition, Washington State Univ., Pullman. p 59.

Pettigrew, J. E. 1981. Supplemental dietary fat for peripartal sows: A review. J. Anim. Sci. 53:107.

Pollmann, D. S., D. M. Danielson, M. A. Crenshaw and E. R. Peo, Jr. 1980. Long term effects of dietary additions of alfalfa and tallow on sow reproductive performance. J. Anim. Sci. 51:294.
Pond, W. G. and K. A. Houpt. 1978. The Biology of the Pig. Cornell Univ. Press, Ithaca, NY.

Reese, D. E., B. D. Moser, E. R. Peo, Jr., A. J. Lewis, D. R. Zimmerman, J. E. Kinder and W. W. Stroup. 1982a. Influence of energy intake during lactation on the interval from weaning to first estrus in sows. J. Anim. Sci. 55:590.

Reese, D. E., B. D. Moser, E. R. Peo, Jr., A. J. Lewis, D. R. Zimmerman, J. E. Kinder and W. W. Stroup. 1982b. Influence of energy intake during lactation on subsequent gestation, lactation and postweaning performance of sows. J. Anim. Sci. 55:867.

Reese, D. E., E. R. Peo, Jr. and A. J. Lewis. 1984. Relationship of lactation energy intake and occurence of postweaning estrus to body and backfat composition in sows. J. Anim. Sci. 58:1236.

Seerley, R. W., F. M. Griffen and H. C. McCampbell. 1978. Effect of sow's dietary energy source on sow's milk and piglet carcass composition. J. Anim. Sci. 46:1009.

Seerley, R. W., T. A. Pace, C. W. Foley and R. D. Scarth. 1974. Effects of energy intake prior to parturition on milk lipids and survival rate, thermostability and carcass composition of piglets. J. Anim. Sci. 38:64.

Seerley, R. W., R. A. Snyder and H. C. McCampbell. 1981. The influence of sow dietary lipids and choline on piglet survival, milk and carcass composition. J. Anim. Sci. 52:542.

Stahly, T. S., G. L. Cromwell and W. S. Simpson. 1980. Effects of level and source of supplemental fat in the lactation diet of sows on the performance of pigs from birth to market weight. J. Anim. Sci, 51:352.

Varley, M. A. and D.J.A. Cole. 1976. Studies in sow reproduction. 4. The effect of level of feeding in lactation and during the interval from weaning to remating on the subsequent reproductive performance of the early-weaned sow. Anim. Prod. 22:71. 